\title{
MARTIN ŠMERDA
}

Masaryk University

\section{Quirinus and his Role in Original Capitoline Triad}

This article is focused mainly on ancient Roman god Quirinus and his origin, character and role in the First Capitoline Triad of ancient roman religion. This article enumerates theories and views of Roman authors on the origin and character of Quirinus as one of the oldest members of ancient Roman pantheon. The available evidence from literary sources pertaining to Quirinus, his priests and festivals is also considered. Author of this article evaluates the similarities between Mars and Quirinus and their priests (Salii and flamines) and possible warlike competences of Quirinus - his connection to war.

Keywords: First Capitoline Triad, Jupiter, Mars, Quirinus, Salii, Flamines, Romulus, Numa

\section{Introduction}

The main focus of this article is the true character of the ancient Roman god Quirinus and his role in the Original Capitoline Triad. Since the literary evidence dated back to ancient Roman and Greek culture comes from a much later period of time - mostly from the $1^{\text {st }}$ century BC and late Roman Empire - there are several general problems: Concerning their religion, even Romans themselves had forgotten the genuine purpose and origin of some of their archaic rituals and gods because of the several centuries long gap between the age of Roman Kings to the times of the end of the Republic and the reign of early Roman emperors, when most of the literary sources available for this era were written. Therefore, we should not consider everything a historical fact, but more likely an artistic recreation of a mythical history from the Roman perspective corresponding to the time it was written. We should also consider the purpose of each source text we use - whether to approach it as historical evidence or a philosophical treaty regarding the ideal conditions of things or whether the purpose of the text was to set a perfect example of Roman virtues based on the historical background. 


\section{First Capitoline Triad and Quirinus in ancient sources}

The first Capitoline Triad consisted of Jupiter, Mars and Quirinus and crowned the Roman pantheon from the times of Romulus to the reign of the Etruscan kings of Rome. Concerning Quirinus there are sources to be found containing a number of theories about his possible descent, character and role in accounts of several Roman and Greek authors.

Varro mentions in his artwork De Lingua Latina ${ }^{1}$ that the mons Quirinalis was named either after the sanctuary of Quirinus that was situated there or that it was derived from Quirites, people of Sabine town of Cures, who had come to Rome with their king Titus Tatius and settled there. Therefore it is assumed that Quirinus might originally have been a Sabine protective god, as Jupiter was to the Romans and as Mars was to all the Italic tribes.

Livy mentions another possibility of the development of Quirinus in his Histories ${ }^{2}$. After the death of Romulus, Proculus Iulius, a member of a class dubbed patres at the time, saw the spirit of the deceased Romulus in his dream and was told that he, Romulus, became Quirinus, and if Romans worshipped him, he would lead them to power and dominance ${ }^{3}$.

On this account, Romulus was deified after his death and assumed the place and name of Quirinus. This was a common view of Quirinus in Livy's times, most likely supported by Caesar and Augustus, who presented Romulus as their ancestor. Quirinus thus became the protective god of Roman citizens, who started dubbing themselves Quirites after their founder King. As Romulus and Remus were believed to be sons of Mars, and Mars was believed to be son of Jupiter and Juno, this

\footnotetext{
${ }^{1}$ Varro LL 5, 51: Collis Quirinalis, <quod ibi> Quirini fanum. Sunt qui a Quiritibus, qui cum Tatio Curibus venerunt ad Roma<m>, quod ibi habuerint castra.

2 Liv. 1, 16: Namque Proculus Iulius, sollicita civitate desiderio regis et infensa patribus, gravis, ut traditur, quamvis magnae rei auctor, in contionem prodit. "Romulus" inquit, "Quirites, parens urbis huius, prima hodierna luce caelo repente delapsus se mihi obvium dedit. Cum perfusus horrore venerabundusque adstitissem petens precibus ut contra intueri fas esset, "abi, nuntia" inquit "Romanis, caelestes ita velle ut mea Roma caput orbis terrarum sit; proinde rem militarem colant sciantque et ita posteris tradant nullas opes humanas armis Romanis resistere posse.
}

${ }^{3}$ Liv. 2, 16; see last sentence in footnote nr. 2. 
would mean that the First Capitoline Triad consisted of Jupiter, Mars and Quirinus who were grandfather, father and son.

The third account is dated back to a much later period of Roman history and was written by Maurus Servius Honoratus, who, on the turn of $4^{\text {th }}$ and $5^{\text {th }}$ century AD wrote his commentary to Virgil's Aeneid ${ }^{4}$. There he wrote his comment on the verse Remo cum fratre Quirinus iura dabunt. He commented that Mars is dubbed Gradivus when he is furious (he who walks to the battle), and when he is calm, he is Quirinus. He also noted that there were two of his temples in Rome: one dedicated to Quirinus inside the City, being a calm guardian; the second one was situated outside the sacred borders of the City on Via Appia close to the gate and was dedicated to Mars Gradivus, a stout warrior marching into battle.

In the same commentary to Virgil's Aeneid ${ }^{5}$ follows more information on the difference between Mars and Quirinus. The difference according to the author is that Quirinus was an aspect of Mars presiding over peace and safety, and who as such had his seat inside the City; Mars Gradivus on the other hand was presiding over war and had a more active role - as such he had his temple outside the City. According to these two notions of Maurus Servius Honoratus, there might have been a view of Quirinus being a protector of the City of Rome and its citizens, who as such had a temple inside the pomerium, the sacred border of Rome. Mars, on this same account, as a warrior god, who walked from the City into battle, had a temple outside. On that Georges Dumézil $^{6}$ commented in his Archaic Roman Religion (1970) that Quirinus and Mars represented two contrasting yet changing aspects of the same people. Because when Rome was in war, male citizens of Rome (quirites) entered into military service to protect their fatherland and so from the quirites by the means of military oath they became soldiers (milites).

\footnotetext{
${ }^{4}$ Serv. A. 1, 292: Mars enim cum saevit Gradivus dicitur, cum tranquillus est Quirinus. Denique in urbe duo eius templa sunt: unum Quirini intra urbem, quasi custodis et tranquilli, aliud in Appia via extra urbem prope portam, quasi bellatoris, id est Gradivi.

${ }^{5}$ Serv. A. 6, 859: Quirinus autem est Mars, qui praeest paci et intra civitatem colitur: nam belli Mars extra civitatem templum habuit.

${ }^{6}$ DUMÉZIL (1970: 262).
} 
When war ended, soldiers were honorably discharged from their oath and service and became citizens again.

\section{Broader perspective - priests and festivals}

Above-mentioned accounts can also be complemented with the accounts concerning certain priestly colleges of Rome. Some authors such as Livy and Dionysius of Halicarnassus ${ }^{7}$ wrote about the reign of Numa Pompilius and his new religious institutions including the creation of flamines, personal priests of important gods. These flamines were divided into flamines maiores and flamines minores. Livy provided us with an account ${ }^{8}$ on the flamen Dialis, who was of the highest respect. He was a personal priest of Jupiter, who was charged with keeping his rites, which originally belonged to the competence of the Roman king. To the flamen Dialis Numa added two other flamines maiores - the flamen Martialis and the flamen Quirinalis.

Among other new religious institutions of Numa was the College of Salii Palatini, which consisted of twelve dancing priests, who had their seat on the Palatine hill. Their college was later complemented by the decree of Tullus Hostilius ${ }^{9}$ by another college of twelve Salii Agonales or Salii Collini, who had their seat in mons Quirinalis. Both colleges are attested and described quite extensively in Roman Antiquities by Dionysius of Halicarnassus ${ }^{10}$. The Salii were dressed in tunicae pictae ${ }^{11}$, with

7 D.H. 2, 64: The first division of religious rites he assigned to the thirty curiones, who, as I have stated, perform the public sacrifices for the curiae. The second, to those called by the Greeks stephanêphoroi or "wearers of the crown" and by the Romans flamines; they are given this name from their wearing caps and fillets, called flama, which they continue to wear even to this day.

${ }^{8}$ Liv. 1, 20: Tum sacerdotibus creandis animum adiecit, quamquam ipse plurima sacra obibat, ea maxime quae nunc ad Dialem flaminem pertinent. Sed quia in civitate bellicosa plures Romuli quam Numae similes reges putabat fore iturosque ipsos ad bella, ne sacra regiae vicis desererentur, flaminem Iovi adsiduum sacerdotem creavit insignique eum veste et curuli sella adornavit. Huic duos flamines adiecit, Marti unum, alterum Quirino;...

${ }^{9}$ Liv. 1, 27: Tullus in re trepida duodecim vovit salios...

${ }^{10}$ D.H. $2,70$.

${ }^{11}$ Colourfully embroidered tunics. 
iron breastplates over it, and maybe also in toga trabea ${ }^{12}$ over the breastplate. They were armed with archaic shields called ancilia and spears and their ceremonial purpose was to leap-dance in a specific three-step rhythm during a festival in a procession through the streets of Rome while also singing the sacred songs ${ }^{13}$ and carrying the shields and spears. To both of these colleges belonged the twelve sacred shields ( $a n-$ cilia - according to myth one of the shields was an original shield of Mars sent to Earth from the Heavens and the rest were eleven unrecognisable copies made by Mamurius Veturius. Both colleges shared the duty of keeping these shields safe and well cared for.

Salii Palatini were devoted to Mars Gradivus (Mars, who walks into battle), and the Salii Collini to Quirinus. Salii Palatini were doing their part in March during the festival of Tubilustrium (on the $23^{\text {rd }}$ of March). Their duty was to ritually begin the period of military campaigns in a new year - ancilia movere. Salii Collini were doing their part in the festival of Armilustrium (on the19 $9^{\text {th }}$ of October) and after that they put the arms and shields to winter sleep (ancilia condere) marking the end of the period of military campaigns in the year coming to end. In other words Salii Palatini of Mars Gradivus opened the period for war and military campaigns (from March to October) and Salii Collini of Quirinus ritually laid arms to rest and opened the period of winter peace under the vigilant watch of Quirinus.

Concerning the character of Quirinus, according to the aforementioned accounts, he was quite similar to Mars and to some extent connected to war, but in a different manner than Mars. After his connection with deified Romulus, Quirinus gathered more peaceful connotations he became the protector of the City, the state and of all Roman citizens, who started to call themselves Quirites after him, the deified founder of their eternal city. With his function as the protector of the people of

\footnotetext{
12 According to D.H. 2, 70: „They wear embroidered tunics girt about with wide girdles of bronze, and over these are fastened, with brooches, robes striped with scarlet and bordered with purple, which they call trabeae; this garment is peculiar to the Romans and a mark of the greatest honour."

${ }^{13}$ Liv. 1, 20: Salios item duodecim Marti Gradivo legit tunicaeque pictae insigne dedit et super tunicam aeneum pectori tegumen caelestiaque arma, quae ancilia appellantur, ferre ac per urbem ire canentes carmina cum tripudiis sollemnique saltatu iussit.
} 
Rome were connected some parts of everyday life which he also protected in some manner through his personal flamen. The participation of the Flamen Quirinalis is attested at only three festivals other than the Quirinalia (festival of Quirinus). Two of them, the Robigalia ${ }^{14}$ and the Consualia, were both agricultural festivals. The Robigalia, attested by Ovid, was being held on the $25^{\text {th }}$ of April to protect the growing grain from harm by cereal rust ${ }^{15}$. In Ovid's Fasti a poetic prayer ${ }^{16}$ of flamen Quirinalis to Robigo can be found, after which follows the description of the sacrificial offering of the blood and entrails of a dog (catulus).

The Ludi Consuales (or the Consualia) were two festivals held to honour the god Consus, a tutelary god of harvest and stored grain. According to Livy ${ }^{17}$ and Plutarch ${ }^{18}$, his cult and games were founded by Romulus - his Ludi were held on the $21^{\text {st }}$ of August and Romulus used this as an opportunity to invite Sabines to the Games and to abduct Sabine women. Participation of flamen Quirinalis on this festival is attested by Tertullian ${ }^{19}$ in his artwork De Spectaculis. According to this the flamen Quirinalis together with Vestal virgins made a sacrifice in the underground temple of Consus, which was unearthed only for the purpose and duration of the festival.

Romanian historian of religion Mircea Eliade ${ }^{20}$ divided the gods of First Capitoline Triad according to their role, character and spheres of influence. Jupiter was without a doubt the sovereign god, the thunderer and ruler of heaven. But he didn't reign over war, which was in the competence of Mars, who represented for all Italics the warrior god. Quirinus was associated with peace, but most closely he was related to the assembly of Roman people (co-virites $=$ Quirites). He was the god of the third function in the Indo-European tripartite division.

\footnotetext{
14 Ov. F. 4, 905-942.

${ }^{15}$ A fungal disease of grain ruining the affected crops.

16 Ov. F. 4, 911-932.

17 Liv. 1, 9.

18 Plut. Rom. 14.

19 Tert. Spect. 5, 7.

${ }^{20}$ ELIADE (1982: 123-124).
} 
German classical philologist Georg Wissowa ${ }^{21}$ held a different view. He divided the later cult of Quirinus as deified Romulus from the original archaic cult of Quirinus pater, whom he saw as the patron of the hillcommunity of the Quirinal Hill (similar to Reatinus pater being the patron of Reate). Wissowa suggested that because of the same character of both colleges of Salii and the mention of weapons of Quirinus ${ }^{22}$, the genuine character of Quirinus may have been in the beginning very similar to Mars.

According to Wissowa, Quirinus was the youngest of the gods of the Triad and his flamen was of lowest rank amongst the flamines maiores. Quirinus was strongly connected to his seat on the Quirinal Hill. Varro wrongly counted the Roman community on the Quirinal Hill as being of Sabine descent, and also wrongly thought that Quirinus was a Sabine god. Flamen Martialis also played his ritual part in the service of some other smaller deities ${ }^{23}$ during their festivals.

Wissowa placed the beginning of popular opinion that Quirinus was deified Romulus to the last century of the Republic. Augustus probably included Quirinus in this new meaning as the deified Romulus in the collective sacrifice to Vulcanus on Volcanalia (23 rd of August). Wissowa also mentioned, that in old formulas to Quirinus there appeared Hora Quirini, about whom we know nothing but the name. Ovid $^{24}$ wrote a story in his Metamorphoses about Romulus' wife Hersilia, who was summoned after the death of Romulus to the Quirinal Hill by Juno and from there ascended to heaven, was dubbed Hora and was worshiped beside her husband, Quirinus.

Quirinus without a doubt had some connection to war and the military even though he might have held the more peaceful status of a protector than a warrior. We should consider our knowledge about him still as being limited and we should consider the scarcity of ancient accounts, their being from different times and their different levels of credibility. The true origin and character of Quirinus was quite a mystery for Ro-

\footnotetext{
${ }^{21}$ WissoWA (1912: 153-156).

22 Verg. Georg. 3, 27: Gangaridum faciam victorisque arma Quirini.

${ }^{23}$ For example Larenta, Robigus and Consus.

${ }_{24}$ Ovid. Met. 14, 829-851.
} 
mans and is still mysterious to us as we can see in the few selected different examples of what the great scholars of modern times had to say about this interesting Roman god.

\section{Bibliography}

DUMÉZIL 1970

G. DuMÉZIL: Archaic Roman Religion with an Appendix on the Religion of the Etruscans. Vol. 1. Transl. P. Krapp. Chicago 1970.

ELIADE 1982

M. ElIADE: A History of Religious Ideas. Vol. II, From Gautama Buddha to the Triumph of Christianity. Transl. W. Trask. Chicago 1982.

Wissowa 1912 G. WissoWA: Religion und Kultus der Römer. München 1912. 